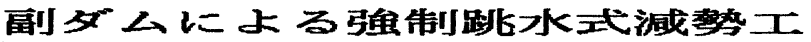

Forced Hydraulic Jump Type Energy Dissipators with Endsills

建設省土木研究所 正員 角 哲也

\title{
1.はじめに
}

ダム放流水の滅势方法として最も一般的である「副ダムを有する跳水式滅势工」は、下流水位が跳水を起こ させるための共役水深に满たない場合に、副タムによる下流水位の確保と、跳水位置の安定化を目的として設 計されるが、この場合には規模や形状を決定するための目標となる対象流量が設定され、その流量が完全な跳 水により減势されるように考虑される。

ところで、日本の洪水防御をその目的の一つとする賍水池では、その洪水調節中に計画論上放流することと なる最大流量、すなわち計画最大放流量 $(\mathrm{Q} f)$ と、ダム地点の洪水規模としての計画高水流量 $(\mathrm{Q} k)$ が設 計条件として考虑される。一方、ダムおよび洪水吐き設計の最大流量であるダム設計洪水流量 ( $\mathrm{Q} d)$ につい ても、タムのの安全性を低下させるべきではないとの考えで設計される。この場合、これらの流量相互の関係は 個々のダムによって異なるが、通常、 $\mathrm{Qf} / \mathrm{Qk}=0.1 \sim 0.6 、 \mathrm{Qd} / \mathrm{Qk}=1.2 \sim 2.0$ 程度と、その比がかなり 大きくなっている。

減勢工は、下流の河道や河川管理施設等に対しては、基本的に計画最大放流量以下の流量を確実に減勢出来 れば良いことになるが、河川の従前の機能の維持という覞点から、計画高水流量やダム設計洪水流量を無視す ることは適当でない。このため、滅勢工の設計においては、減勢機能をダムの水理構造物である減勢工および 下流の河道にどのように配分するかが重要となっており、これらの流量の幅を考慮した上で、かつ、経済性の 面からの種々の検討も加えて適切な規模を求めなくてはならない。

本報文は、ある設定された滅勢工規模に対して流量が変化した場合に、完全跳水状態から不完全跳水状態へ と遷移する一連の水理現象を把握することを主眼としている。当然のことながら、この場合、副ダムの機能は 当初の下流水位の確保を目的とするものから抗力を受けるシルに近いものに変化しており、その水理特性を明 確にしなければならない。従来、シルとしての強制跳水に関する研究は、Rajaratnam ${ }^{2}$ や、大津 ${ }^{3}$ '等によって 行われてきているが、このように、本来、背上げ効果を期待して設置される副ダムに対して、流入量の增加と ともにその水理機能が変化する状態を系統的に研究した例は少なく、明確な設計基準が確立されていないため に、実際のダムの設計においても模型実験によって武行的に検討されているのが垷状である。

\section{2. 跳水式減勢工の設計}

従来より、完全跳水を目指す対象流量 $Q_{0}$ に対して、跳水始端が水吒き始端位固に一致し、また副ダム前面 において共役水梁 h j が確保されるように副ダム高D及び水吅き長Lが決定されている（図一 1）。 通常副ダム高の算定式として（1）式が用いられているが、これは次の a) - c) の仮定によっている。

$$
\mathrm{Dj} / h_{1}=\frac{\left(1+2 F_{1}^{2}\right) \sqrt{1+8 F_{1}^{2}}-1-5 F_{1}^{2}}{1+4 F_{1}^{2}-\sqrt{1+8 F_{1}^{2}}}-\left(\frac{\sqrt{\mathrm{g}}}{C} F_{1}\right)^{\frac{2}{3}}
$$

a ）断面 I - II 間は、水平水路上の跳水であり、比力一定により共役水樑 h $\mathrm{j}$ （断面 II）が得られる。

b ) 断面 I ーII間のエネルギー損失が無視出来るとして、副ダム越流量が（2）式で示される。

$$
\mathrm{q}=\mathrm{C}\left(\mathrm{E}_{2}-\mathrm{D}\right)^{3 / 2} \quad \mathrm{E}_{2}=\mathrm{v}_{2}{ }^{2} / 2 \mathrm{~g}+\mathrm{h}_{2}
$$

c）断面 I，II で静水圧分布、また運動量係数 $\beta=1$ である。

ここで副ダム流量係数Cは、自然越流時の流量係数として通常1.9 2.0程度を用いているが、これは副ダム 形状と越流水深との関係に依存するものである。 
一方、水叨き長しは副ダム上流面に動水

圧が作用して跳水の形態が変化しないよう

に（3）式で求めている。

$\mathrm{Lj}=4.5 \mathrm{hj}$

このように、副ダムを有する跳水式減勢

工は、跳水計算を行う対象流量を決定すれ ば容易に設計できるが、その設備がダム設 計洪水流量以下の流量レンジに対して持つ 総合的な減勢機能を知って初めて減勢工と しての是非が判定できる。

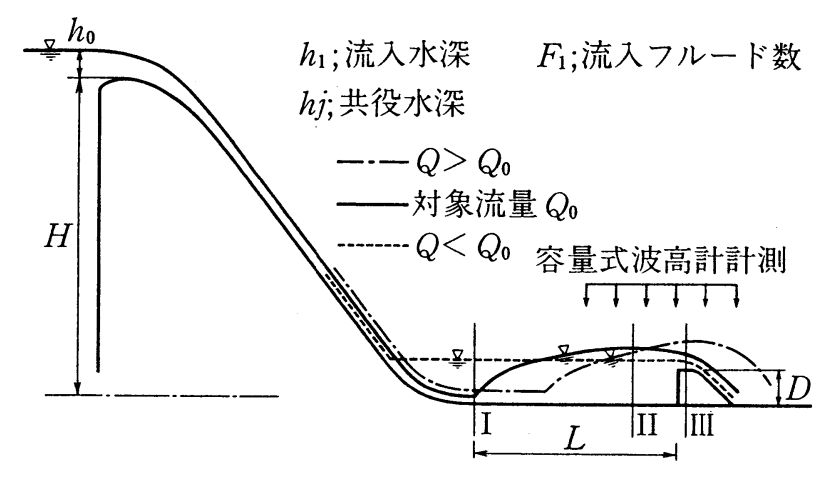

\section{3. 跳水式滅勢工の水理模型実殹}

図-1副ダム式水叫き

\section{1 実験椥要}

対象流量Q。が与えられれば、それに対応した減勢工は先に示したように計算されるが、実際に設計された 滅勢工に対して、その対象流量を上回る流量が流入した場合に不完全跳水状態となる減勢池の水理特性を明ら かにするために次のような検討を実施した。なお、ここでは、副ダム下流水深が小さく、減勢池における跳水 形態に影響を与えない堨合とする。

実験では、跳水の基本的特性を検討するために 2 次元水路（水路愊 $\mathrm{B}=100 \mathrm{~cm}$ )とし、滅勢池上流側に、堤体 導流部（ $\mathrm{H}=200 \mathrm{~cm}$, 勾配 $1: 0.8)$, バケットカーフ (半径 $\mathrm{r}=40 \mathrm{~cm})$ を設置した。一方、副ダムに関しては、 流量係数が予め湘定してあるものを使用し、副ダム高 $\mathrm{D}$ をパラメータ（D=17，21，25，29，33cm）として幾 何学的に相似な形状を用いており、水吒き長Lも各副ダムことに 3 ケースずつ変化させている。計測は、減势 池内の水面形及びその変動、断面最大流速、及び副ダム作用圧力であり、また、流況の分類も行っている。

ここで、流入条件としては、単位愊流量 $\mathrm{q}$ 、越流水深 $\mathrm{h}_{0}$ 、及び水吒き始端における流入水深 $\mathrm{h}_{1}$ を測定し、 計算により、フルード数 $\mathrm{F}_{1}$ 、及び断面平均としての流入流速 $\mathrm{v}_{1}$ を求めている。対象とした範囲は、 $\mathrm{q}=66 \sim$ $556 \mathrm{l} / \mathrm{s} 、 \mathrm{~h}_{0}=10.0 \sim 42.4 \mathrm{~cm} 、 \mathrm{~h}_{1}=1.3 \sim 8.5 \mathrm{~cm} 、 \mathrm{~F}_{1}=7.12 \sim 14.2$ である。

\section{2 実験条件の整理}

一般に、副ダムによる強制跳水における水理特性値 $\mathrm{f}$ は、（4）式によって示されるものと推定され、また 次元解析によれは、（5）式となる。

$$
\begin{array}{r}
f=f\left(h_{1}, D, L, q, g, C\right) \\
f=f\left(D / h_{1}, L / h_{1}, F_{1}, C / \sqrt{g}\right)
\end{array}
$$

ところで、任意の流量に对して、設計計算式 (1)，（3）を用いて得られる減势工を（D j, L j ）と定 義する。一方、見実に存在する隇势工規模を（D，L）とすれは、この滅勢工の任意の流量に対する有効度の パラメータとして、副ダム高に関してD／D j、水吒き長に対してL L L j を取上げることが出来る。この （D j，L j）の中には $\mathrm{h}_{1} や \mathrm{~F}_{1}$ の効果が含まれており、減勢池の流況を整理するために（6）式のような関 係が成り立つのではないかと推論される。

$$
f=f(D / D j, L / L j)
$$

\section{4. 跳水式減勢工の水理特性}

4. 1 強制跳水の跳水長

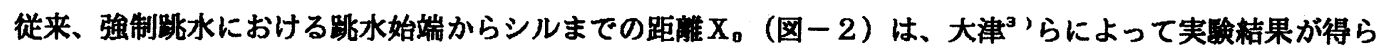
れており、図に示すように $\mathrm{X}_{0} / \mathrm{L} j \sim \mathrm{D} / \mathrm{h}_{1} \sim \mathrm{F}_{1}$ の関係で整理される。今回の実倹では、上流㑡に堤体が 
存在するために、比較的高い副ダムの場合には潜り跳水状態 $\left(\mathrm{L} / \mathrm{X}_{0}<0.95\right)$ となって、実際に計測出来な

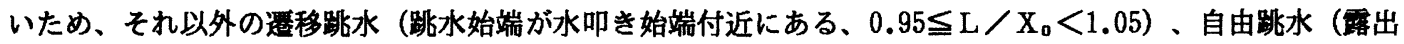

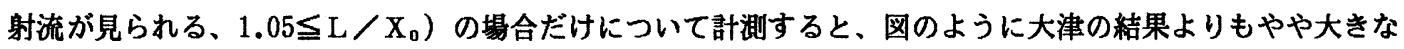
值となった。これは、大津の場合、天端幅 $\mathrm{b}$ の比較的小さい刃形シルに近い形状を用いているのに対して、 今回の実験では、 $\mathrm{b} / \mathrm{D}=0.6$ 程度の通常の副ダム形状を想定したため、同じ $\mathrm{D} / \mathrm{h}_{1}$ でも $\mathrm{X}_{0} / \mathrm{L} j$ が異なる 結果となっているようである。また、Rajaratnam、大津らはL $j$ を自然跳水における跳水長としているが、こ こでは設計水叫き長 $4.5 \mathrm{~h} \mathrm{j}$ を用いて代表している。

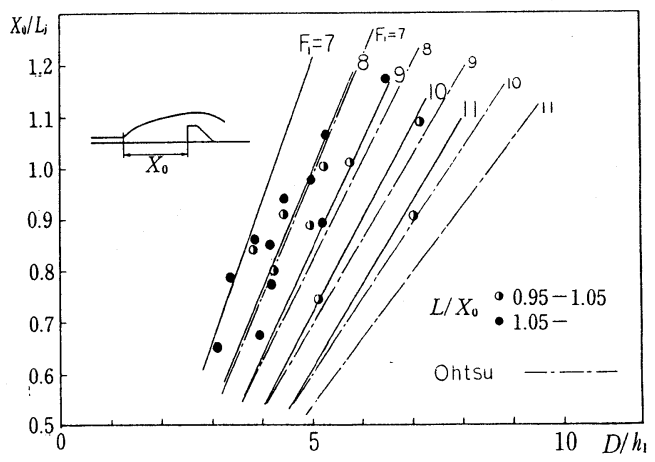

図-2 強制跳水の跳水長 （a）

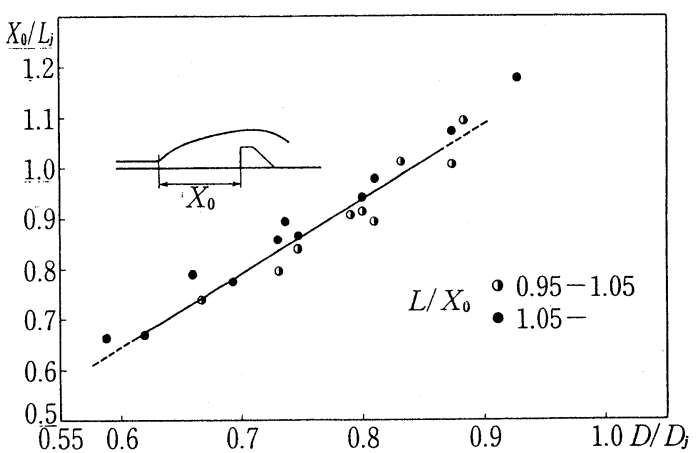

図-3 強制跳水の跳水長

(b)

次に、これをD/D j のパラメータを用いて整理してみると、図ー3のように、概ね、同棣の傾向を示して おり、この整理方法が有効であることが明らかとなった。ただし、 $\mathrm{F}_{1}$ の大きく異なる場合にもこの関係が成 立するかどうかは不明であるが、今回の実験範囲 $7 \leqq F_{1} \leqq 11$ 程度では良い相関が得られるようであり実験式

（7）を得た。

$$
\mathrm{X}_{0} / \mathrm{Lj}_{\mathrm{j}}=-0.229+1.46(\mathrm{D} / \mathrm{Dj})
$$

\section{2 滅勢池流況}

実検により得られた流況を図ー4 に示す。流況は、まず跳水始端に関 して、先に示したように潜り跳水、 遷移跳水、自由跳水の 3 形態に分類 できる。これによれば、D／D j> 1.0 では潜り跳水となり、 $\mathrm{D} / \mathrm{D} \mathrm{j}$ $<1.0$ では L $/ \mathrm{L} \mathrm{j}$ との関係で状態 が変化し、潜り跳水と自由跳水の境 界である堅移跳水は4．1で整理し た $\mathrm{X}_{0} に つ い て L / \mathrm{X}_{0}=1.0$ となる 堨合であり図中の実線で示される。 また、副ダム付近の水面形を調べ るために、図一 1 のように容量式波 高計を副ダムの前後 $20 \mathrm{~cm}$ 間隔に 6 本 配置して、各点における平均水位と

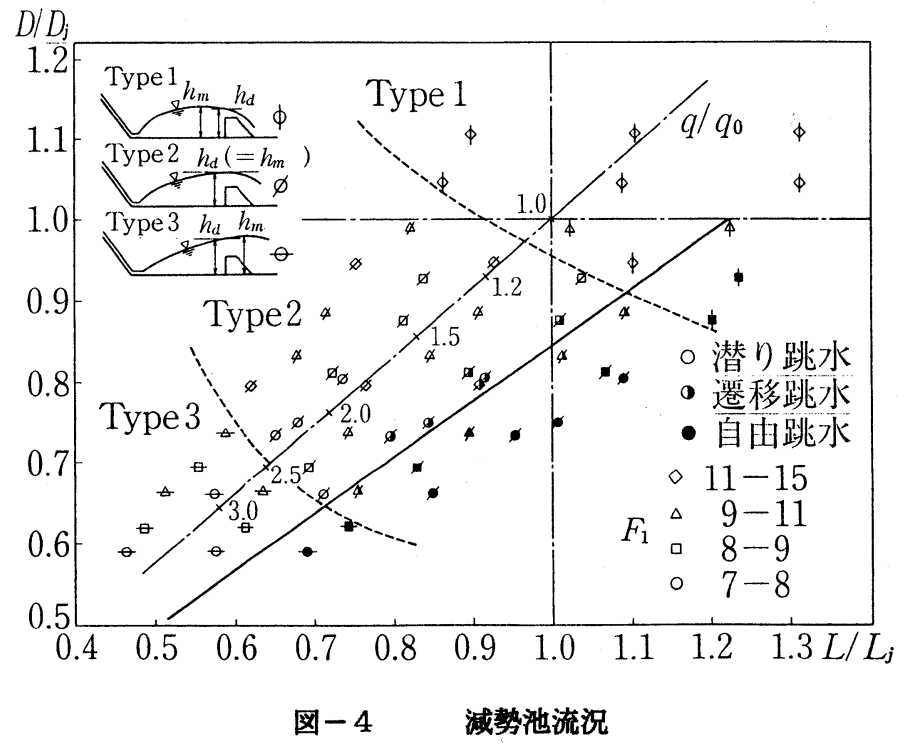


その変動を測定した。そして、6 点の平均水位の最高値 $\mathrm{h}$ mと副ダム上流面上の水位 $\mathrm{hd}$ dと比較から、Type1 (副ダム上流で h mとなる)、Type2（hdが hmとなる） Type3（副ダム下流で $\mathrm{hm}$ となる）の3つの流況に分類 した。なお、写真一 1 はそれぞれの流況を示している。 また、図中の一点鎖線は $(\mathrm{D} / \mathrm{D} j, \mathrm{~L} / \mathrm{L} j)=$ $(1.0,1.0)$ となる時の流量を $\mathrm{q}_{\mathrm{o}}$ とした揚合の流量比 $\mathrm{q} / \mathrm{q}_{\mathrm{o}}$ を、1 例として堤高 $100 \mathrm{~m} 、 \mathrm{q}_{\mathrm{o}}=30 \mathrm{~m}^{3} / \mathrm{s} / \mathrm{m}$ の 場合について試算したものであり、これは堤高や q。が 多少変っても大きな差は見られない。

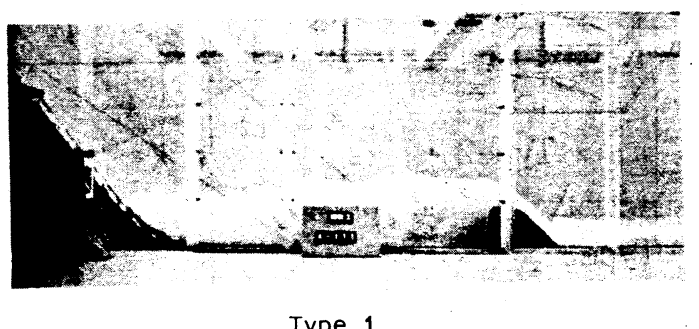

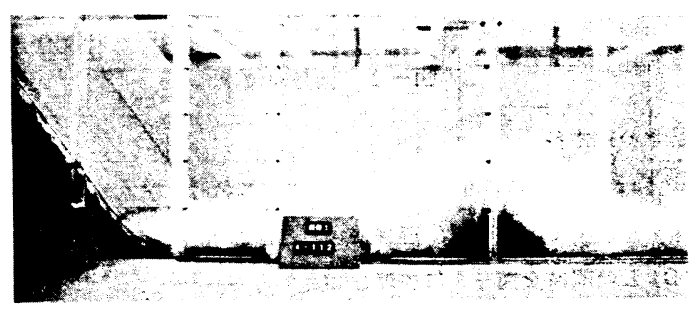

Type 2

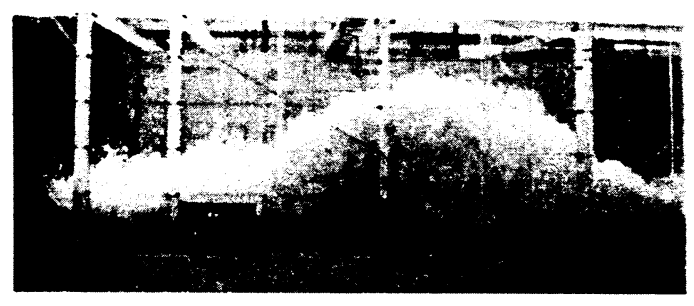

Type 3

写真 -1

4.3 副ダム作用動水圧

副ダム上流面の中央及び壁沿いの 2 測線 に、ピエゾ管を $3 \mathrm{~cm}$ 間隔で埋設して水頭を 測定した。また、この場合の静水圧水頭と して、波高計から得られる副ダム上流面水

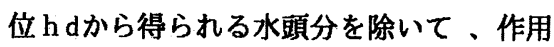
動水圧を 2 湘線の平均により求めている。 シルへの作用動水圧を示す指標として、 抗力係数 $\mathrm{Cd}\left(=(\mathrm{P} / \mathrm{W}) /\left(\mathrm{v}_{\mathrm{i}}{ }^{2} \mathrm{D} / 2 \mathrm{~g}\right)\right)$ が従来より用いられており、計測結果は Rajaratnamと同様に $\mathrm{Cd} \sim \mathrm{X}_{0} / \mathrm{L} j$ の関係 で図ー5のように整理され、Rajaratnamの 定義による I 、II 型から正型への強制跳水 の遷移がうまくとらえられている。ところ で、 $\mathrm{L} / \mathrm{X}_{\mathrm{o}}<0.95$ の潜り跳水の場合には、

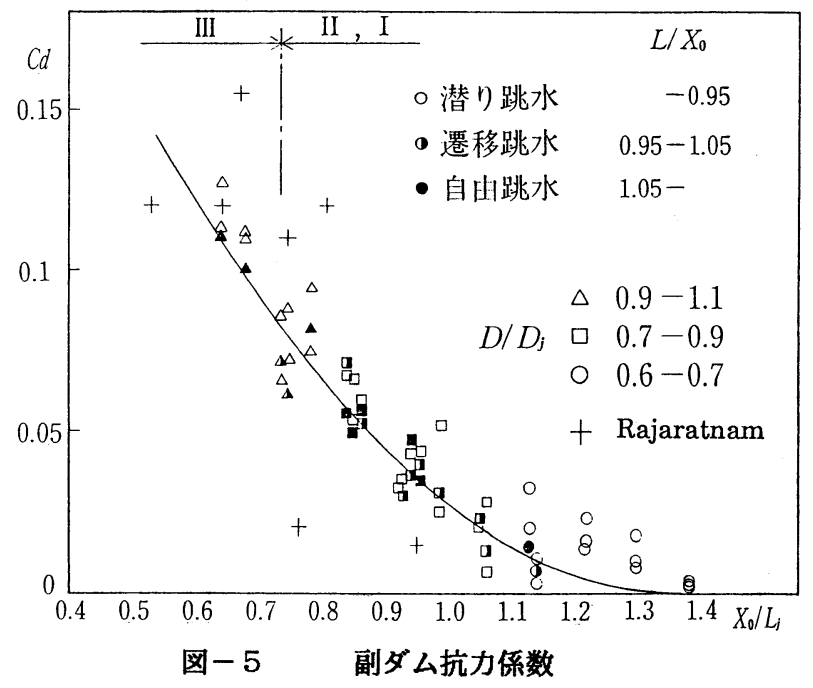

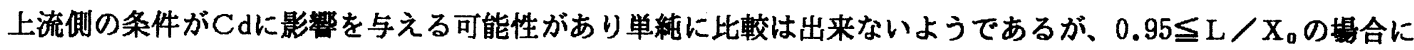
は良い相関関係があり実験式 (8) を得た。

\section{4 滅勢池内平均水位最高値}

$$
\mathrm{C}_{\mathrm{d}}=0.390-0.572\left(\mathrm{x}_{0} / \mathrm{L}_{\mathrm{j}}\right)+0.211\left(\mathrm{x}_{0} / \mathrm{L}_{\mathrm{j}}\right)^{2}
$$

容量式波高計で得られた 6 点の平均水位の最高値 $\mathrm{h} m$ 学 $\mathrm{h}$ jで無次元化したものを図一 6 に示す。図一 4 に示 すよjに、Type 1-3では hmの場所が異なっている。一般に、D/D jの增加に従って $\mathrm{hm} / \mathrm{h} \mathrm{j}$ も大きくな り、当然のことながら $\mathrm{D} / \mathrm{D} \mathrm{j}>1.0$ では $\mathrm{hm} / \mathrm{h} j>1.0$ となり、必要以上の副ダムであることを示している。

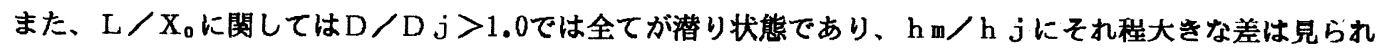

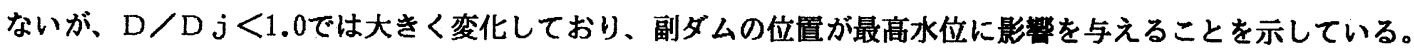




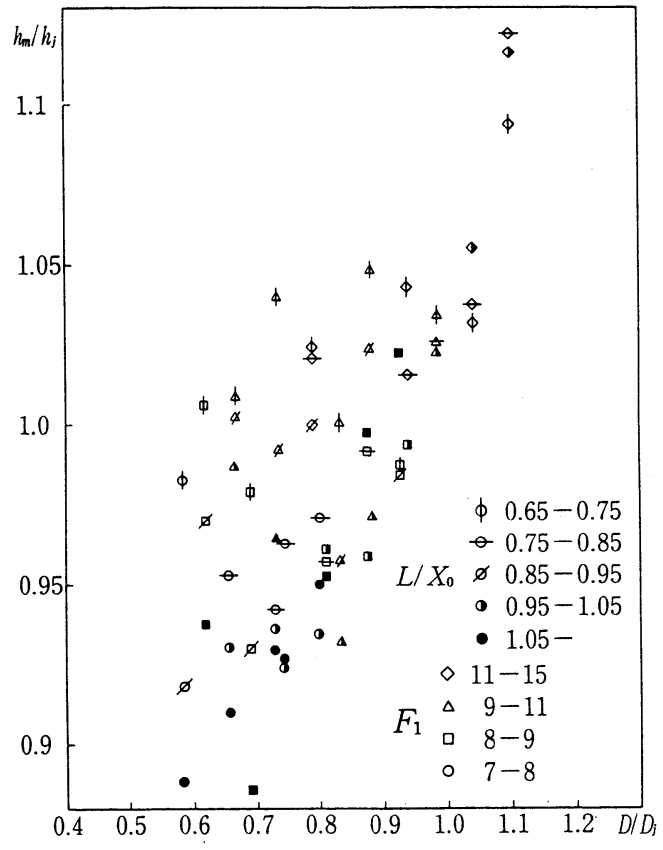

図-6 隇势池内平均水位最高值

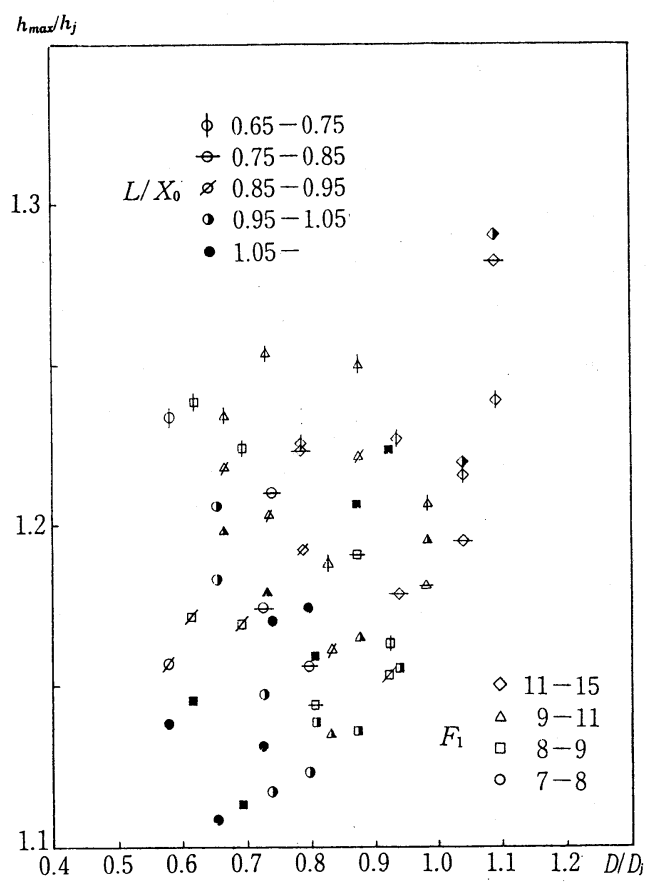

図-8 減勢池内最高水位最高值

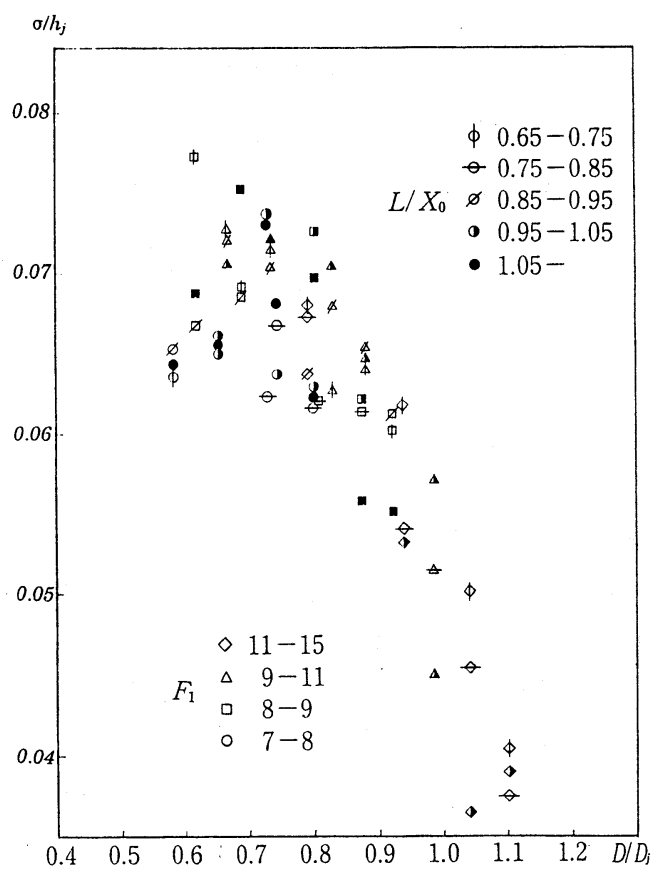

図-7 副ダム上水位変動

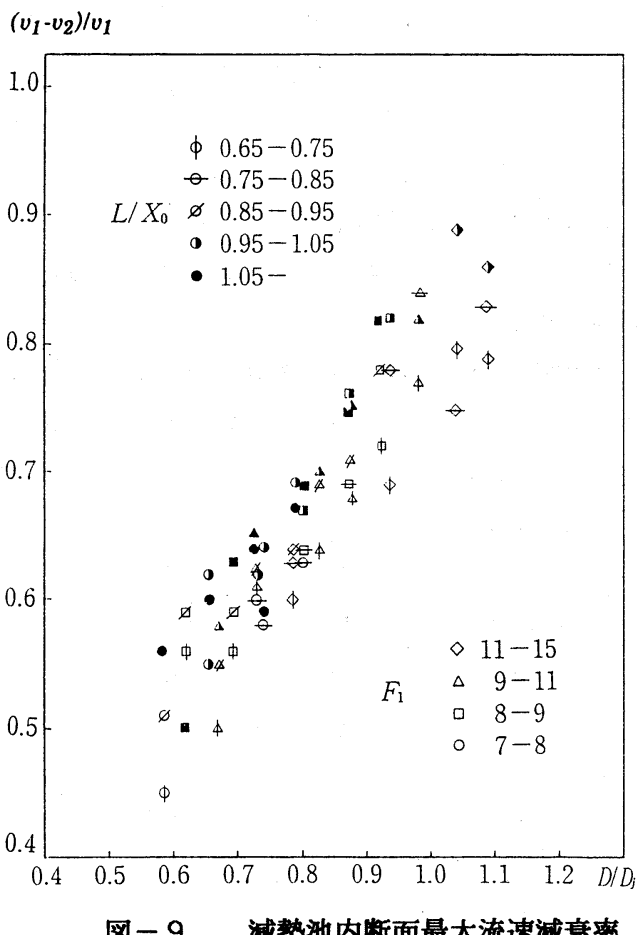

\section{5 副ダ么上水位変勤}

次に、滅勢池流況の判断の 1 つの資料として、副ダム前面位固における水位変動の標準偏差 $\sigma$ を整理すると 
图一7のようになる。予想されるように、D/D j が小さくなると $\sigma$ は増大するが、D $/ \mathrm{D} j=0.7$ 付近でピ 一クを持ち、これは、これより副ダムが低くなると跳水が副ダム下流へ飛び出し始めるために、水位変動の最 大値も下流へ移るものと考えられる。全般に潜り跳水、自由跳水の差はあまりなく、通常の隇勢池において想 定される $0.8 \leqq \mathrm{D} / \mathrm{D} j$ の場合には $\sigma / \mathrm{h} j \leqq 0.06$ 程度と考えておけはよいことになる。

4.6 滅勢池内最高水位最高値

通常、一定の時間間隔における瞬間的な最高水位 $\mathrm{h}$ maxは平均水位 $\mathrm{hm}$ 十標準偏差 $\sigma \times 3$ に一致しているよう であり、この值が滅勢池側壁高の設計に関して大きな意味を持っている。ここで、 $\mathrm{h} \max$ の発生位固は $\mathrm{hm}$ 異 なる場合もあるが全般に同位置となっているようであり、実呀により得られた $\mathrm{h} \max =\mathrm{hm}+3 \sigma$ を同様に整理 したものが図ー8である。この場合、 $\mathrm{h} \mathrm{m}$ と比較してD/D j の小さい部分でのばらつきが大きくなり、特に、

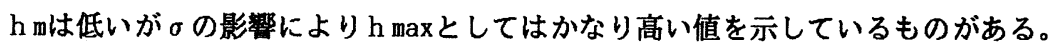

\section{7 隇勢池内断面最大流速隇衰率}

滅势池の持つ滅勢特性の 1 つとして、流入流速 $\mathrm{v}_{\mathbf{1}}$ と副ダム上流 $\mathrm{D}$ の位固における断面最大流速 $\mathrm{v}_{\mathbf{2}}$ を比較し て、その滅勢状態を評価することが出来る。この場合、潜り跳水では上流側における隇勢の影響があり、また 自由跳水時には露出区間が減勢区間として寄与しないことになるが、ここではそれらも全て含めて、副ダム前 面までに隇勢された流速の効果により比較を行った。その結果を図ー9に示すが、D/D j が小さくなるに従 って滅勢状態も悪くなって来ていることが明らかである。しかしながら、滅勢工としての機能限界を求めるた めには、この凟料だけでは不十分であるが、一応の目安になるものと考えられる。

\section{5.おわりに}

今回の検討では、減勢工における副ダムの機能としての従来の考え方の幅を広げて、大流量時には多少の抗 カが作用するような流況も想定した上で、設計に際して必要となる不完全跳水時の水理特性を明らかにした。

一方、始めに述べたように減勢工の設計において検討すべき流量には幅があり、その幅の中で実際に選定す る滅勢工規模をどこに求めるかが大きな課題となってくる。ところで、図一 2 において、 $\mathrm{q} / \mathrm{q}_{\mathrm{o}}$ を軸に流量 比と（D/D j, L / L j ）の関係を示したが、この様に同一の隇势工に対して流量を変化させるということ は、図中においてある特定の直線上を動くことに相当し、計画では、隇勢工に課せられた流量レンジをどのよ うに割り付けるかが重要となる。さらに言い換えれば、隇勢工の設計問題は、最も流況が悪くなるダム設計洪 水流量Qdに対する（D／D j, L / L j ）を、いくらに設定するかという議論に集約されることになる。

この設定については、現状では明確な評価の基準がなく、減勢効果がどこまで維持されるか等の研究が進め られなけれはなならい。例えば、副ダム付近の流況が減勢効果の1つの基準になるとすれば、すべての流量に 対してType2までとなるように、Qdの場合に（D／D j >0.7，L/L j>0.65）を満足するような（D，L） を逆算して求めればよいことになる。また、副ダム下流にどの程度のエネルギーが減勢されずに残るのかも重 要な要素の 1 つであり、河床洗掘に与える影響などとの関連で検討すべき問題である。従って、減勢工の規模 を求めることは、単に隇勢池内の流況を满足させるだけではなく、副ダムを中心に、その下流の一定区間をも 含めた中で最も適切な形状を得ることと考えるべきであるう。

\section{6. 参考文献}

1）田村正秀 : 跳水式隇勢工の設計と水理模型実駼, 国際大ダム会議第 11 回大会講演集, 1973

2) Rajaratnam, N. : The forced hydraulic jump, Water Power, No. 1, 1964

3）大津岩夫：鉛直シルによる強制跳水，土木学会論文報告集，第311号，土木学会，1981年7月

4）角 哲也：副ダムを有する跳水式減勢工の水理特性，土木技術資料，Vol.28，No.10，1986

5）水理公式集, 昭和60年度改訂版, 土木学会 